and toxicities in other crops have been adapted to cacao, and symptoms have been produced in sand and water cultures. The description of these symptoms by E. J. Maskell, H. Evans and D. B. Murray, illustrated by fourteen colour-plates and numerous half-tone reproductions, will be a standard work of reference. Indications were found that micro-element deficiencies are common in cacao in Trinidad and other West Indian islands, and curative methods are being developed.

Other environmental factors. As cacao is commonly grown under shade, it is good to see that a critical investigation of the effects of shade on growth has been started, on which a progress report is presented by $H$. Evans and D. B. Murray. Preliminary findings are that optimum light intensity for young cacao in the first year lies between 25 and 60 per cent of full sunshine; there is evidence that the optimum increases with size of plant and consequent selfshading; the effect of fertilizers is less marked at low than at high light intensities; and there are differences between clones in behaviour under the various treatments.

Pests and diseases. R. E. D. Baker reviews briefly research on witches' broom disease (Marasmius perniciosus Stahel). Locally selected clones vary widely in their susceptibility to this disease, though none is immune. Immune or very highly resistant material from the Upper Amazon is being used in the breeding programme.

T. W. Kirkpatrick gives an account of the insect vectors of a Trinidad cacao virus. This virus, though less destructive than the most virulent strains of swollen-shoot virus in West Africa, appreciably reduces yield and is under close study.

Preparation and quality of cocoa. Quality is determined by genotype, growing conditions and the preparation (fermentation and drying) by which fresh cacao beans are converted into the 'raw cocos' of commerce. The first two are field factors governing the composition of the fresh seeds as harvested; their interactions can be studied by using clonal material. F. Hardy, G. Rodrigues and F. Haworth describe variations in nitrogenous components of the bean as influenced by genotype, soil type, age of tree, season and environment. This work is a useful start in a field where much more is needed.

The microbiology and biochemistry of the changes occurring during fermentation and drying are likewise vast fields of research which have only recently been entered. Some preliminary work on the enzymes of cocoa tissue by K. W. De Witt should be useful in this connexion. The same author describes apparatus for small-scale fermentation, which is an attempt to solve one of the most urgent short-term problems in cacao research to-day. New varieties produced by the plant breeders, however good their agricultural performance, cannot be recommended for commercial planting until it is ascertained that they will suit the chocolate manufacturer as well as the grower; but so far it has proved impossible to assess quality satisfactorily from samples prepared on a small scale, and time, land and effort have to be wastefully expended in multiplying trees to produce large bulks of seeds for tests. Full explanation of the differences between large and small bulks in fermentation may take long to get; but a technique for judging quality from small samples, however empirical, must be found soon if progress is not to be halted.

\section{FORESTRY RESEARCH IN GREAT BRITAIN}

$\Gamma \mathrm{H}$ HE report by the Forestry Commission on forest research in Great Britain for the year ending March 1951* is divided into two parts : the work carried out by the research staff of the Forestry Commission; and research undertaken on behalf of the Commission by universities and other institutions. In an introduction by James Macdonald, director of research and education, it is noted that forestry research has to be undertaken in branches outside the purely scientific. Last year a section dealing with mechanization of forestry operations was formed. With an advisory committee having been set up on the utilization of home-grown timbers during the year under review, a new section was established to carry out investigations into the marketing and utilization of produce from woodlands in Britain. This new section will keep in touch with the Forest Products Laboratory at Princes Risborough. There were no major developments in sylviculture, but a summary is given in the report of interesting work on the natural regeneration of the old Scots pinewoods in the Highlands; and another article is on the use of larch in mixture in the formation of oak plantations, a subject which has been studied in the south of England for a number of years-in fact, with the example extant in the Forest of Dean, for nearly a century. A point of interest is the survey of plantations which had been formed on old ironstone workings in the Midlands, on which a further report is awaited. The research station at Alice Holt, which has already outgrown its capacity, has been equipped for seed-testing, and the Commission's stocks of seed are already being tested there. A considerable amount of experimental work was carried out in connexion with forest nurseries. It is perhaps open to doubt whether the reclassification of derelict woodland areas recorded in the census of woodlands for the south-east and south-west conservancies of England yet gives the true picture of their real position.

The thirty-third annual report of the Forestry Commission gives the record of the activities of the Commission for the year ending September 30, 1952†. The report opens with a tribute to the late Lord Robinson, chairman of the Commission, who died on September 5, 1952. As technical commissioner during 1919-32 and chairman for the past twenty years, Lord Robinson played a great part in organizing the Forestry Commission and shaping its policy, and his death is a great loss to British forestry.

Under the heading "General Review", the report deals with the stress laid by the Chancellor of the Exchequer on the need for economy in national expenditure. Foresters who have served in various forest services in the British Commonwealth have all had experience of this call from the financial minister; one of the first blows has often fallen upon the forest department, with consequences-not fully appreciated, it is admitted-which resulted in delaying progress. The Commissioners have closely reviewed their present, as well as their future, commitments. To a large extent these commitments are connected

- Forestry Commission. Report on Forest Research for the Year ending March 1951. Pp. vi $139+4$ plates. (London: H.M.S.O., 1952.) $4 s, 6 d$

+ Forestry Commission. Thirty-third Annual Report of the Forestry Commission for the Year ended September 30th, 1952. Pp. 90. (London .H.M.S.O. ,1953.) 38. net. 
with the expanding programme begun in 1945. The progressive increase in the area planted, from 26,000 acres in the forest year 1947 to more than 61,000 acres in the year covered by the present report, has involved increases in nursery ground and plant stocks and housing accommodation. The steady progress in the Dedication Scheme involves a higher outlay, while on the administration side the Forestry Act of 1951 places extra duties in connexion with felling licences on the staff, and the Commission has to face the rise in wages of forest workers. Reduction in expenditure was therefore by no means an easy task.

The Commissioners have been guided by two considerations : first, the maintenance, tending and protection of existing woods must have priority-an obvious necessity; secondly, every endeavour will have to be made to maintain the present rate of planting, in order to avoid waste and the sacrifice of nursery stock, and the rate of the preparatory work, fencing, ploughing, draining, etc., already undertaken or in progress. Economies will be made in housing, road development, staff cuts and general administration.

In spite of these troubles, the existing forestry estates have been maintained, and, as already noted, an area of 61,000 acres has been planted during the year. Of this area, 22,000 acres (36 per cent) consisted of replanting, that is, restocking felled or devastated woodland or serub-a most meritorious piece of work and the highest proportion yet reached. As one result of the thirty years of planting, it was possible to increase by 4,400 acres the area thinned in the plantations, the greater part of the increase being in Scotland; this is the beginning of a return on the expenditure already incurred. Progress in private forestry is reported on favourably, and the Dedication Scheme is said to be making substantial headway.

The disastrous 'windblow' in Scotland during the end of December 1951 and the middle of January 1952 is dealt with at some length. The Commission's plantations escaped comparatively lightly, the timber blown over on scattered small areas amounting to about 300,000 cubic feet. The windfall on private estates amounted to nearly four million cubic feet of timber, there being cases in Sutherland and Caithness of whole woods being laid flat. All species suffered, including Scots pine and oak and other broad-leaved species.

The report shows that the Commission can claim to have already laid the foundations in Britain of a forestry estate which, under correct management, will prove of inestimable value to the country. Correct perpetual management involves working plans, and on the subject of such plans the Commission almost appears to suffer from a slight inferiority complex. The report admits that "the forest working plan is essentially a document which describes the existing tree crops and the conditions under which they are growing, which specifies in more or less detail the work to be carried out during the period of the plan, and which provides for records to show what progress has been made". It is the intensity upon which the plan is made that is the obstacle. Because, in the case of long-managed and -regulated existing forests, the working plan is elaborate and made for ten or more years, it is difficult to understand why "the professional forester should regard only the complete, text-book type of plan as worthy of the name". What is the text-book type ? It is obvious that such plans would be out of place and could not, in fact, be made for the large areas of young forests of the Commission. But simple plans for a short period of years are comparatively easy to make and work, and these are fully entitled to the name of working plan. They are not merely plans of operationsthese latter contain prescriptions which can be modified almost at will; but prescriptions laid down in the working plan, once sanctioned by the highest authority, can only be modified or altered by that authority.

E. P. Stebbing

\section{STERIC EFFECTS IN THE ELECTRONIC SPECTRA OF ORGANIC COMPOUNDS}

\section{By DR. E. A. BRAUDE, DR. F. SONDHEIMER* and $D_{R}$. W. F. FORBES $†$ \\ Department of Organic Chemistry, Imperial College} of Science and Technology, London, S.W.7

DROFOUND changes in the ultra-violet light absorption of organic molecules due to substituents (such as methyl groups), the effects of which must be predominantly steric rather than electronic, were first noted by Pickett ${ }^{1}$ and by Rodebush $^{2}$ in the case of diphenyls and acetophenones ${ }^{3}$. Many other examples have since been described and this phenomenon has been associated, in general terms, with spatial interference which opposes the adoption by the chromophoric system of the uniplanar arrangement required for most effective conjugation. In a more detailed discussion, a distinction was drawn between two different types of spectral manifestations of steric inhibition of uniplanarity : (1) steric effects which only cause a change in the absorption in intensity (that is, transition probability) of the band characteristic of the whole chromophoric system, but no unusual change in wave-length ; (2) steric effects which cause a change in both wave-length (that is, transition energy) and absorption intensity. It was concluded that effects of type (1), which are encountered less frequently, occur whon steric inhibition is comparatively weak; whereas effects of type (2), which are rather more common, occur when steric inhibition is comparatively strong.

The physical interpretation of the second type of steric effect is fairly clear; steric inhibition of electronic interaction normally raises the energy-level of the excited state more than that of the groundstate, thus increasing the transition energy and resulting in a hypsochromic shift of the band and an attendant change in intensity. On the other hand, the physical interpretation of the first type of steric effect is much less obvious. The absence of unusual wave-length displacements means that the separation of the energy-levels of the ground- and excitedstates is almost unaffected by the substituent and, since the nature of the transition is evidently unaltered, the transition moment àssociated with any individual absorption act must also be unchanged; yet the macroscopic transition probability is reduced. Such a phenomenon is not inherent in classical theory and requires the postulate of a new principle. It was suggested" that steric effects of

* Present address : Syntex, S.A., Mexico City, Mexico.

† Present address: Memorial University of Newfoundland, St. John's, Canada. 